\title{
Notes on COVID 19 and the Contradictions of Capital II
}

\author{
Anthony Marcus ${ }^{1,2} \cdot$ Winnie Lem ${ }^{3}$
}

Accepted: 13 December 2021 / Published online: 28 December 2021 (c) The Author(s), under exclusive licence to Springer Nature B.V. 2021

The commentaries in this issue are a response to a call for a follow- up to Notes on COVID 19 and the Contradictions of Capital, a symposium published in the September 2020 issue of Dialectical Anthropology (44:3)

In our second symposium on COVID 19, we asked for commentaries that explore the possibility for socialist resolutions to the current chaos. We asked for these commentaries in light of our belief that the forces that undermine the political consciousness and concerted action of the international working class have been successful at exploiting the pandemic, and that none of the political institutions that lead or seek to lead the working class have the ability right now to engage in the forecasting, planning and execution necessary to provide an alternative anti-capitalist praxis. All this is, despite an unprecedented increase in social struggle around the planet.

Our call asked for contributions that unpack and parse these processes, and think about what the future might look like. What scenarios are the capitalist class preparing for action and reaction and how might we respond? Hope is famously dangerous, but we asked authors to consider what a socialist solution and plan for a pandemic free future could look like.

As we approach 2022, we are still being bombarded with headlines about mutant viruses, Delta and Omicron variants, vaccine nationalism, one in a million allergic reactions, and the ubiquitous phrase "Coronavirus is here to stay". These narratives have limited our ability as a class to conceive and construct socialist resolutions. In the heat of the current pandemic moment, pessimism, fear, lack of hope, virus-inspired culture wars, divided polities and authoritarian solutions seem to be the only offerings coming from above. Indeed, the international bourgeoisie thrives in an atmosphere of chaos, fear, hopelessness, and social atomization. Perhaps this is the reason for wild runups in share prices amidst death, conflict, combat, "virus

Anthony Marcus

toniomar@yahoo.com

Winnie Lem

wlem@trentu.ca

1 La Trobe University, Bundoora, Australia

2 City University of New York, New York, NY, USA

3 Trent University, Peterborough, ON, Canada 
fatigue", the wholesale destruction of small businesses, and the ruination of petty bourgeoisies across the planet. Many amongst this class seem to increasingly view nationalism, fascism, and nostalgia as the only solution to their untenable present and hopeless future.

While it is challenging to look to the future when the present is so chaotic, an old cliché observes that "it is always darkest before the dawn". We have sought contributions that assume a coming dawn and offer insights on different global contexts, and consider, from a socialist perspective, such questions as: What will the future look like? What should the future look like? How do we get from here to there? What class forces are at work, who are their antagonists and what are they doing?

Anthony Marcus

Winnie Lem

Publisher's note Springer Nature remains neutral with regard to jurisdictional claims in published maps and institutional affiliations. 